\title{
Killer Whales in Hawaiian Waters: Information on Population Identity and Feeding Habits ${ }^{1}$
}

\author{
Robin W. Baird, ${ }^{2}$ Daniel 7. McSweeney, ${ }^{3}$ Christopher Bane,${ }^{4}$ Fay Barlow, ${ }^{5}$ Dan R. Salden, ${ }^{6}$ \\ La'Ren K. Antoine, ${ }^{3}$ Richard G. LeDuc, ${ }^{5}$ and Daniel L. Webster ${ }^{3}$
}

\begin{abstract}
Killer whales (Orcinus orca) have only infrequently been reported from Hawaiian waters, and most of what is known about killer whales worldwide comes from studies in coastal temperate waters. Here we present 21 records of killer whales from within the Hawaiian Exclusive Economic Zone between 1994 and 2004. Killer whales were recorded nine months of the year, most around the main Hawaiian Islands. Although there were more records than expected during the period when humpback whales are abundant around the Islands, there is likely an increase in sighting effort during that period. Killer whales were documented feeding on both a humpback whale and cephalopods, and two species of small cetaceans were observed fleeing from killer whales. Although it is possible that there are both marine mammal-eating and cephalopod-eating populations within Hawaiian waters, it seems more likely that Hawaiian killer whales may not exhibit foraging specializations as documented for coastal temperate populations. Saddle patch pigmentation patterns were generally fainter and narrower than those seen in killer whales from the temperate coastal North Pacific. Analysis of skin samples from two animals indicated two mitochondrial haplotypes, one identical to the "Gulf of Alaska transient 2" haplotype (a mammal-eating form), and the other a new haplotype one base different from haplotypes found for mammal-eating killer whales in coastal Alaskan waters.
\end{abstract}

Killer whales (Orcinus orca) are distributed worldwide, but most of what is known about their biology comes from studies in the more accessible coastal temperate areas (Baird

${ }^{1}$ Field research was supported primarily by the Southwest Fisheries Science Center of NOAA Fisheries and the Wild Whale Research Foundation. Manuscript accepted 12 December 2005.

${ }^{2}$ Cascadia Research Collective, $218 \frac{1}{2}$ West 4th Avenue, Olympia, Washington 98501 (e-mail: rwbaird@ cascadiaresearch.org).

${ }^{3}$ Wild Whale Research Foundation, Box 139, Hōlualoa, Hawai'i 96725.

${ }^{4}$ HoloHolo Charters, 4353 Waialo Road, Suite 5A, 'Ele'ele, Hawai'i 96705.

${ }^{5}$ Southwest Fisheries Science Center, NOAA Fisheries, 8604 La Jolla Shores Drive, La Jolla, California 92037.

${ }^{6}$ Hawai'i Whale Research Foundation, 52 Cheshire Drive, Maryville, Illinois 62062-1931.

Pacific Science (2006), vol. 60, no. 4:523-530

(C) 2006 by University of Hawai'i Press

All rights reserved
2000). Prey documented for killer whales includes a diversity of taxa, including cephalopods, bony and cartilaginous fishes, reptiles, birds, and mammals (Hoyt 1990, Jefferson et al. 1991). In high-latitude areas in both the Northern and Southern Hemispheres, however, coastal populations are known or thought to specialize on certain types of prey, either fishes or marine mammals (Baird et al. 1992, Simila et al. 1996, Pitman and Ensor 2003). A suite of evidence (genetic, morphological, and behavioral) from these temperate coastal populations has been used to delineate a number of distinct and apparently reproductively-isolated populations, many of which are sympatric (Baird and Stacey 1988, Stevens et al. 1989, Baird et al. 1992, Hoelzel et al. 1998, 2002, Pitman and Ensor 2003).

Little is known of the diet of killer whales in the tropics and oceanic areas. Theoretically, killer whales in tropical and oceanic areas (i.e., low-productivity areas) should be 
less likely to exhibit prey specializations (Baird 2002); diet breadth should increase as the availability of the most highly profitable prey decreases (Baird 2002; see also Pitman and Dutton 2004). The relationship between tropical oceanic populations and the betterstudied temperate populations is also unknown, though given the high degree of structure existing in temperate populations (e.g., Hoelzel et al. 2002), it seems likely that killer whales in tropical oceanic areas may be reproductively isolated from the temperate populations. Despite the paucity of studies in the tropics, their overall abundance there may be quite high. For example, Wade and Gerrodette (1993) provided an estimate for the eastern tropical Pacific of 8,500 individuals. However, density is low in the tropics (Forney and Wade 2006), resulting in little directed research on killer whales.

Sightings in Hawaiian waters are infrequent. Mobley et al. (2001) reported a sighting from March 2000 off the island of Nicihau and noted that the most recent previously confirmed record was from 1979. In this report we review and present recent records of killer whales around the main Hawaiian Islands and discuss aspects of their biology based on observations of feeding habits and reactions of other species to killer whales. We also speculate on population discrimination based on external morphology and genetic analyses of two killer whale samples collected around the main Hawaiian Islands.

\section{MATERIALS AND METHODS}

Sightings of killer whales in Hawaiian waters were compiled from several sources, including directed cetacean surveys or research projects, commercial whale- and dolphinwatching operations or sportfishing charter operators, and newspaper reports and other published literature. When available, photographs were used to confirm species. In all four cases when fishing vessel charter operators reported killer whales and photographs were available, species identification was confirmed by R.W.B. as killer whales. Given the distinctive color patterns and the ease of discriminating killer whales, as well as their high public profile, we believe that records of animals from all sources were likely correctly identified to species. Photos were also used to examine pigmentation patterns in relation to population discrimination, and photographs of distinctive individual whales were compared with catalogs of mammal-eating killer whales from western Alaska (held at the National Marine Mammal Laboratory, Seattle; J. Durban, pers. comm.) and all killer whales documented from the tropical Pacific (held at the Southwest Fisheries Science Center, La Jolla; P. Olson, pers. comm.). Photographs from different records within Hawai $i$ were also compared to address movements of individuals. Mean group size was calculated using all sightings; when only a range in group sizes was available for a particular record the midpoint in the range was used in calculating mean group size. Observations of feeding behavior or reactions of other cetaceans to the presence of killer whales were noted from original observers. Skin samples were collected from one live individual using a remote biopsy system, and from one dead animal, and were stored in a dimethyl sulfoxide (DMSO)/salt solution for genetic analyses.

Genetic analyses of skin samples were undertaken at the Southwest Fisheries Science Center. The entire mtDNA control region was amplified in two overlapping segments from extracted genomic DNA (Qiagen DNeasy \#69506). The 5' fragment was amplified using primers H16498 [primer names reference their location within the fin whale sequence published in Árnason et al. 1991] (5'-cctgaagtaagaaccagatg- $3^{\prime}$ [Rosel et al. 1994]) and L15812 (5'cctccctaagactcaaggaag- $3^{\prime}$; developed at the Southwest Fisheries Science Center). The 3' fragment was amplified using DL3C (5'gtgaaaccagcaaccegc- $\left.3^{\prime}\right)$, and $12 \mathrm{SC}\left(5^{\prime}-\right.$ aaggctgggaccaaacctt- $3^{\prime}$ ), both developed at the Southwest Fisheries Science Center. Using the same primers, both strands of each amplified DNA product for each specimen were sequenced independently as mutual controls using standard protocols on the Applied Biosystems Inc. (ABI) model 3100 sequencer. All sequences were aligned using Sequencher software, version 4.1 (Genecodes). 
TABLE 1

Records of Killer Whales in Hawaiian Waters since 1994 (Multiple Records in the Same Area on the Same Day Are Listed Once)

\begin{tabular}{|c|c|c|c|c|c|c|c|}
\hline Date & Island/Area & $\begin{array}{l}\text { Group } \\
\text { Size }\end{array}$ & $\begin{array}{l}\text { Lat. } \\
\left({ }^{\circ} \mathrm{N}\right)\end{array}$ & $\begin{array}{l}\text { Long. } \\
\left({ }^{\circ} W\right)\end{array}$ & Evidence $^{a}$ & Comments & Source \\
\hline 18 July 1994 & W Hawai'i & 5 & 19.90 & 156.25 & E.F.C.O. & & W. Casey ${ }^{b}$ \\
\hline 15 Aug. 1994 & W Hawai'i & 6 & 19.75 & 156.18 & E.F.C.O. & & $\begin{array}{l}\text { M. Parker, }{ }^{b} W \text {. } \\
\text { Casey }^{b}\end{array}$ \\
\hline 18 Jan. 1996 & W Hawai'i & 2 & 19.39 & 156.01 & E.F.C.O. & & N. Issacs ${ }^{b}$ \\
\hline 18 Aug. 1997 & E Kaua'i & 1 & & & Photos & & S. K. Salibi \\
\hline 12 Jan. 1998 & W Hawai'i & 2 & 19.77 & 156.20 & Photos & $\begin{array}{l}\text { Harassing humpback } \\
\text { whale }\end{array}$ & L. Antoine, J. Ross ${ }^{b}$ \\
\hline 15 Jan. 1998 & W Hawaici & 3 & 19.68 & 156.08 & E.F.C.O. & & D. Boudea ${ }^{b}$ \\
\hline 18 Jan. 1998 & W Hawai'i & 3 & 19.37 & 155.99 & E.F.C.O. & & N. Issacs ${ }^{b}$ \\
\hline 30 Jan. 1998 & W Kaua'i & $1^{c}$ & 21.9 & 159.88 & E.O. & & C. Bane \\
\hline 6 Mar. 1998 & NE Ni'ihau & $4-5$ & 22.03 & 160.02 & E.O. & & C. Bane \\
\hline 18 May 1998 & F. F. Shoals ${ }^{d}$ & 3 & 23.5 & 166.0 & E.O. & & I. Kinan \\
\hline Feb. 2000 & W Hawai'i & 4 & & & Photos & $\begin{array}{l}\text { Avoidance by Stenella } \\
\text { attenuata }\end{array}$ & C. Haupert \\
\hline 20 Mar. 2000 & SW Ni'ihau & 5 & 21.82 & 160.33 & Photos & & Mobley et al. (2001) \\
\hline 20 Mar. 2001 & Kaua'i & 5 & 21.93 & 159.88 & Photos & $\begin{array}{l}\text { Feeding on } \\
\text { humpback whale }\end{array}$ & C. Bane \\
\hline 1 Sept. 2001 & W Lana'i & 6 & 20.65 & 157.14 & Photos & $\begin{array}{l}\text { Feeding on } \\
\text { "octopus" }\end{array}$ & $\begin{array}{l}\text { Shimote (2001), } \\
\text { Roberts and } \\
\text { Meadows (2004) }\end{array}$ \\
\hline mid-Feb. 2002 & W Hawai'i & 4 & 19.66 & 156.21 & Photos & & $\begin{array}{l}\text { K. Mongreig, } \\
\text { Rizzuto (2002) }\end{array}$ \\
\hline 11 Sept. 2002 & Offshore & $3^{e}$ & 26.93 & 179.93 & E.O. & & Barlow et al. (2004) \\
\hline 12 Nov. 2002 & Offshore & $10^{e}$ & 24.34 & 166.23 & Photos & $\begin{array}{l}\text { Feeding on } 1 \text { by } 6 \mathrm{~m} \\
\text { chunk of whale? }\end{array}$ & Barlow et al. (2004) \\
\hline 10 May 2003 & W Hawai'i & 4 & 19.66 & 156.08 & Photos & $\begin{array}{c}1 \text { biopsy, avoidance } \\
\text { by Peponocephala }\end{array}$ & Baird et al. (2003) \\
\hline 18 May 2003 & W Hawai'i & 6 & & & E.O. & $\begin{array}{l}\text { Attacking Stenella } \\
\text { attenuata }\end{array}$ & $\begin{array}{l}\text { T. Bradford, Rizzuto } \\
\text { (2004) }\end{array}$ \\
\hline 25 May 2003 & W Hawai'i & $\sim 6$ & & & E.O. & & $\begin{array}{l}\text { T. Bradford, J. } \\
\text { Heintz }\end{array}$ \\
\hline 6 Apr. 2004 & E Lana'i & 1 & 20.79 & 156.80 & Photos & $\begin{array}{l}\text { Live stranded, squid } \\
\text { in stomach } f\end{array}$ & D. Salden \\
\hline
\end{tabular}

${ }^{a}$ E.F.C.O., experienced fishing charter operator (see text); E.O., experienced observer (individuals with previous and/or subsequent experience with killer whale identification).

${ }^{b}$ Personal communication to D.J.M.

${ }^{c}$ Encounter duration short and in rough seas; therefore group size may have been larger.

${ }^{d}$ French Frigate Shoals.

${ }^{e}$ Group size based on original observer notes; numbers reported incorrectly in Barlow et al. (2004).

$f$ Squid recorded in stomach (M. B. Hanson, pers. comm.).

\section{RESULTS AND DISCUSSION}

We compiled 21 records of killer whales from Hawaiian waters from July 1994 through April 2004 (Table 1). Although only 10 of the records are confirmed by photographs, an additional six were by experienced observers, and the remaining five were by four fishing charter operators with a com- bined $125 \mathrm{yr}$ of fishing experience in Hawai $i$. These latter four individuals have reliably identified several hundred sightings of small cetaceans in past reports confirmed by one author (D.J.M.) and thus their identifications are considered accurate. In two periods (January 1998, May 2003) there were multiple records (two or three) in the same area within a few weeks of each other, and it is possible 
that these represent repeated sightings of the same group of whales remaining in the area for a short period. In each case at least one of these reports was confirmed by photographs (Table 1). Given that Mobley et al. (2001) noted only two known records from 1979 through 2000, this represents either a dramatic increase in the presence of killer whales in Hawaiian waters in recent years or, more likely, an increase in reporting of sightings. These records represent an average of almost two sightings per year around the main Hawaiian Islands. Still, it seems that killer whales should be considered rare around the Hawaiian Islands, given the ease of recognizing this species, the number of potential observers on the water (including researchers on vessel and aerial platforms, as well as commercial whale- and dolphinwatching companies and sportfishing charter operators), and the fact that many of these records are of sufficient public interest to make it into the media. For example, in smallboat-based surveys for cetaceans around the main Hawaiian Islands from February 2000 through November 2005, covering just over $30,000 \mathrm{~km}$ of trackline over 295 days, there were 584 sightings of odontocetes (R.W.B., unpubl. data), yet only one killer whale sighting (the 10 May 2003 record in Table 1). There is one estimate of population size in the Hawaiian Exclusive Economic Zone (EEZ) (an area of almost 2.5 million $\mathrm{km}^{2}$ ), of 349 individuals (Barlow 2006), though the precision of the estimate is low $(\mathrm{CV}=0.98)$. A comparison of density estimates throughout the Pacific (Forney and Wade 2006) indicates that killer whales within the Hawaiian EEZ have among the lowest density of any area.

Group sizes reported from Hawaiian sightings ranged from 1 to 10 individuals (Table 1), with a mean group size of 4.2 $(\mathrm{SD}=2.1)$, similar to the mean group size reported for killer whales in the eastern tropical Pacific (5.4 [Wade and Gerrodette 1993]) and off Peru (4.5 [Garcia-Godos 2004]), and for mammal-eating killer whales in temperate coastal waters of the eastern North Pacific (4.2 [Baird and Dill 1996]).

Precise dates were not available for all records, but there are occurrences in nine different months of the year representing all seasons: winter (January-March), spring (April/May), summer (July-September), and fall (November). Although two records are from waters far offshore to the west (though still within the Hawaiian EEZ), and one is from French Frigate Shoals in the Northwestern Hawaiian Islands, main-island records include all seasons except fall, suggesting that killer whales may use the waters around the main Hawaiian Islands year-round. Mobley et al. (2001) previously noted killer whale records from Hawaiian waters only during the "winter" (DecemberMarch) and commented on the overlap with humpback whales (Megaptera novaeangliae) migrating to the Hawaiian Islands. Eleven of our 21 records (Table 1) were from months (January-April) when humpback whales are most abundant around the Hawaiian Islands. However, despite the fact that these records came from a variety of different sources, it is likely that there is an overall increase in "effort" in winter periods. Five of the 21 records either were recorded incidentally to humpback whale research or came from commercial dolphin- or whale-watching vessels. Some operators run trips year-round, but the majority of trips are during the period of humpback whale abundance. Over the last $20 \mathrm{yr}$ there have been three to six research vessels and 25-30 commercial whale-watching vessels working on a daily basis in the area where humpback whales are most abundant in Hawaiian waters, and yet relatively few sightings of killer whales have resulted. It is possible that killer whales in Hawaiian waters avoid these areas of high vessel traffic. In one sighting (10 May 2003), we observed a sportfishing charter vessel with trolling gear in the water change direction to approach the group of killer whales at approximately $15 \mathrm{~km} / \mathrm{hr}$. Sportfishing charter vessels in Hawaiian waters frequently troll through groups of small cetaceans to try to catch fish that might be associated with the cetaceans. In this case the killer whale group appeared to accelerate and began high-speed traveling away from the vessel. If killer whales in Hawaiian waters are frequently approached in this way it is 
possible that they may avoid areas with large numbers of vessels.

Information on diet of Hawaiian killer whales comes from eight different records (Table 1). The single record of killer whales feeding on a humpback whale off Kaua' $i$ is the first evidence that Hawaiian killer whales feed on humpbacks. In this case the killer whales were first seen after the humpback was already killed, and several whales in the group were seen carrying large $(1-2 \mathrm{~m})$ pieces of flesh that were clearly recognizable as from a humpback whale (e.g., ventral pleats visible [C. Bane, pers. obs.]). Three groups (February 2000, 10 May 2003, and 18 May 2003) were first seen after other cetaceans in the area apparently reacted to the presence of the killer whales by fleeing (i.e., the fleeing animals were the cue for noticing the groups of killer whales). In February 2000, a group of pantropical spotted dolphins (Stenella attenuata) were seen traveling at high speed and the killer whales were noted soon afterward, behind where the group of spotted dolphins had been. On 10 May and 18 May 2003, melon-headed whales (Peponocephala electra) and pantropical spotted dolphins, respectively, were observed swimming at high speed in multiple directions (radiating outward from a central point), with the killer whales appearing near where the animals had first been seen. Such evasive behavior by both species suggests that they viewed the killer whales as a threat, implying that Hawaiian killer whales either feed on small cetaceans, at least occasionally, or may otherwise harass them. In the presence of killer whales that feed exclusively on fish, other species of marine mammals typically show no reaction to their presence (Jefferson et al. 1991), though there have been observations of fish-eating killer whales harassing and even killing other species of marine mammals (Ford et al. 1998; R.W.B., pers. obs.). That Hawaiian killer whales feed on cephalopods was illustrated from two additional records, one observation of a group feeding on an "octopus," and the second of squid beaks recovered from the stomach of a stranded killer whale (Table 1). Although there is no information to determine whether the whales seen feeding on cephalopods are part of the same population as those involved in the humpback whale attack or the groups that elicited the response by melon-headed whales and pantropical spotted dolphins, this diversity of prey types suggests that killer whales in Hawaiian waters may not specialize only on marine mammals as seen in some temperate populations of killer whales in the North Pacific.

Three types of available information are relevant to population discrimination: (1) scarring patterns, (2) external morphology (pigmentation patterns), and (3) genetic analyses of skin samples. Although photographs were available from a number of encounters, photo quality was insufficient in most to recognize distinctive individuals for comparisons among sightings or with killer whale catalogs elsewhere. Comparisons of identification photographs of the four individuals from the 10 May 2003 sighting with the stranded animal from April 2004, with one individual from the February 2002 sighting, and with other catalogs of killer whales (J. Durban, P. Olson, pers. comms.) did not reveal a match. Examination of photographs taken from the 10 May 2003 encounter indicated two individuals with white oval scars indicative of cookie-cutter shark bite wounds (Figure 1), suggesting that these whales spend some portion of their time in the deep waters where cookie-cutter sharks are found, unlike killer whales in the better-studied coastal temperate populations on the west coast of North America. Pigmentation patterns do vary among populations and have been used to address population identity in temperate coastal populations of killer whales (Baird and Stacey 1988). Saddle patch photographs were available from seven individuals from three sightings in Hawai $i$, and all were generally similar to those documented for mammal-eating killer whales from temperate nearshore waters in the eastern North Pacific, with no black intruding into the saddle patch (Baird and Stacey 1988). However, saddle patches were narrower and fainter (Figure 1) than those seen in temperate coastal populations (J. Durban, pers. comm.), similar to those seen for killer whales in the eastern tropical Pacific (P. Olson, pers. comm.). 


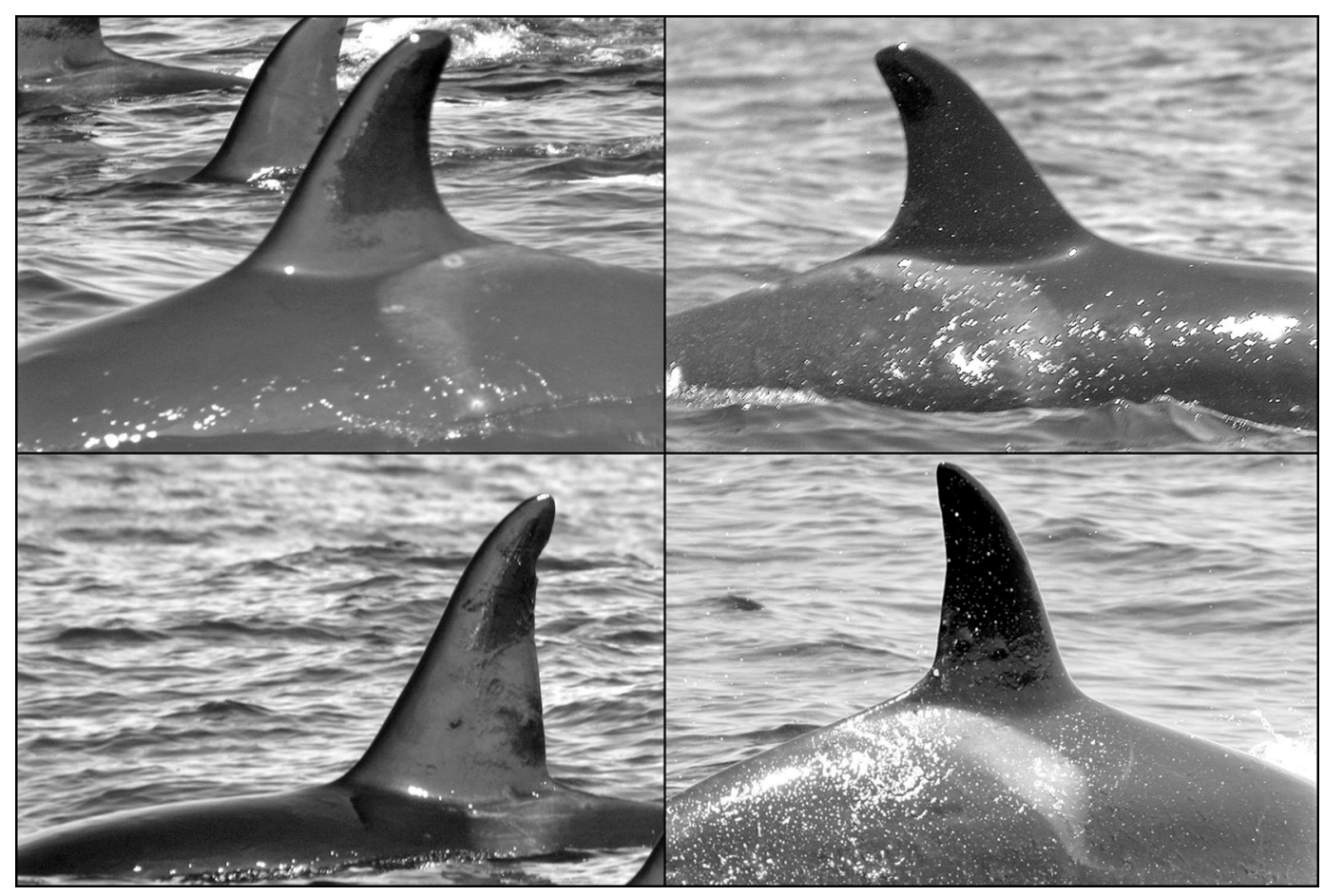

FIgURE 1. Killer whales photographically documented off the west side of the island of Hawai'i, 10 May 2003, showing faint and narrow saddle patches, and white oval scars typical of healed cookie-cutter shark bites.

Two different control region sequences (989 bp) were documented for the two genetic samples. One was identical to the "Gulf of Alaska Transient 2" (GAT2) haplotype; the other was one base different from the GAT haplotype and one base different from the AT1 (Alaska "transient" 1) haplotype (haplotype designations are from Barrett-Lennard 2000). The latter haplotype has been documented once before in Hawaiian waters (Southwest Fisheries Science Center, unpubl. data) but not elsewhere, despite substantial sampling from killer whales throughout the coastal waters of western North America, the Aleutians, the Bering Sea, and eastern Russia (Barrett-Lennard 2000, Hoelzel et al. 2002; Southwest Fisheries Science Center, unpubl. data; combined $n=608$ killer whale samples). Killer whale haplotypic diversity is extremely low, with most populations having only a single mitochondrial haplotype (Hoelzel et al. 2002).
Cetacean density is higher around the main Hawaiian Islands compared with surrounding pelagic areas (Barlow 2006), and several species of cetaceans in Hawai' $i$ have been documented having island-associated populations, some with genetic differentiation suggesting reproductive isolation from populations elsewhere in the tropical Pacific (Galver 2002, Chivers et al. 2003). Both findings are presumably due to higher primary productivity close to shore (Doty and Oguri 1956) and the predictable occurrence of benthic fish and island-associated mesopelagic prey (Reid et al. 1991), encouraging the presence of island-associated populations. The distinctive saddle patch pigmentation patterns and a unique mitochondrial haplotype for Hawaiian killer whales both imply that there may be genetic differentiation from populations from the coastal temperate waters of western North America, though clearly more samples and photographs are needed to con- 
firm this. Whether killer whales in Hawai'i are isolated from killer whale populations elsewhere in the tropical Pacific will require analysis of additional samples collected throughout the tropical Pacific. With one shared mitochondrial haplotype with Gulf of Alaska mammal-eating killer whales, analyses of nuclear DNA will also be required.

\section{ACKNOWLEDGMENTS}

We thank Chuck Haupert and other charter vessel captains and crews for providing information on sightings, Renata Goetzendorfer for providing a photo from the February 2002 sighting, and Kelly Robertson for assisting with genetic analyses. Genetic samples used in the analyses presented here were collected under NMFS Scientific Research Permit no. 774-1437 or provided by the Hawaiian Islands stranding network. Annie Douglas, John Durban, Megan Ferguson, Joseph Mobley, Paula Olson, Gretchen Steiger, and an anonymous reviewer all provided helpful comments on the manuscript.

\section{Literature Cited}

Árnason, U., A. Gullberg, and B. Widegren. 1991. The complete nucleotide sequence of the mitochondrial DNA of the fin whale, Balaenoptera physalus. J. Mol. Evol. 33:556-568.

Baird, R. W. 2000. The killer whale-foraging specializations and group hunting. Pages 125-153 in J. Mann, R. Connor, P. Tyack, and H. Whitehead, eds. Cetacean societies: Field studies in behavior. University of Chicago Press, Chicago, Illinois.

- 2002. Killer whales of the worldnatural history and conservation. Voyageur Press, Stillwater, Minnesota.

Baird, R. W., P. A. Abrams, and L. M. Dill. 1992. Possible indirect interactions between transient and resident killer whales: Implications for the evolution of foraging specializations in the genus Orcinus. Oecologia (Berl.) 89:125-132.

Baird, R. W., and L. M. Dill. 1996. Ecological and social determinants of group size in transient killer whales. Behav. Ecol. 7:408-416.

Baird, R. W., D. J. McSweeney, D. L. Webster, A. M. Gorgone, and A. D. Ligon. 2003. Studies of odontocete population structure in Hawaiian waters: Results of a survey through the main Hawaiian Islands in May and June 2003. Report prepared under Contract No. AB133F-02-CN0106 from the National Oceanic and Atmospheric Administration, Western Administrative Support Center, 7600 Sand Point Way N.E., Seattle, Washington.

Baird, R. W., and P. J. Stacey. 1988. Variation in saddle patch pigmentation in populations of killer whales (Orcinus orca) from British Columbia, Alaska, and Washington State. Can. J. Zool. 66:2582-2585.

Barlow, J. 2006. Cetacean abundance in Hawaiian waters estimated from a summer/ fall survey in 2002. Mar. Mamm. Sci. 22: (in press).

Barlow, J., S. Rankin, E. Zele, and J. Appler. 2004. Marine mammal data collected during the Hawaiian Islands cetacean and ecosystem assessment survey (HICEAS) conducted aboard the NOAA ships $M c A r$ thur and David Starr Fordan, JulyDecember 2002. NOAA Tech Mem. NOAA-TM-NMFS-SWFSC-362.

Barrett-Lennard, L. G. 2000. Population structure and mating patterns of killer whales (Orcinus orca) as revealed by DNA analysis. Ph.D. thesis, University of British Columbia, Vancouver.

Chivers, S. J., R. G. LeDuc, and R. W. Baird. 2003. Hawaiian Island populations of false killer whales and short-finned pilot whales revealed by genetic analyses. Page 32 in Abstracts of the 15th Biennial Conference on the Biology of Marine Mammals, 1419 December 2003, Greensboro, North Carolina. Society for Marine Mammalogy, Lawrence, Kansas.

Doty, M. S., and M. Oguri. 1956. The island mass effect. J. Cons. Int. Explor. Mer 22:33-37.

Ford, J. K. B., G. M. Ellis, L. G. BarrettLennard, A. B. Morton, R. S. Palm, and K. C. Balcomb. 1998. Dietary specialization in two sympatric populations of killer 
whales (Orcinus orca) in coastal waters of British Columbia and adjacent waters. Can. J. Zool. 76:1456-1471.

Forney, K. A., and P. Wade. 2006. Worldwide distribution and abundance of killer whales. In J. A. Estes, R. L. Brownell Jr., D. P. DeMaster, D. F. Doak, and T. M. Williams, eds. Whales, whaling and ocean ecosystems. University of California Press, Berkeley. (in press.)

Galver, L. 2002. The molecular ecology of spinner dolphins, Stenella longirostris: Genetic diversity and population structure. Ph.D. diss., Scripps Institution of Oceanography, San Diego, California.

Garcia-Godos, I. 2004. Killer whale (Orcinus orca) occurrence off Peru, 1995-2003. Latin Am. J. Aquat. Mammal. 3:177-180.

Hoelzel, A. R., M. Dahlheim, and S. J. Stern. 1998. Low genetic variation among killer whales (Orcinus orca) in the eastern North Pacific, and genetic differentiation between foraging specialists. J. Hered. 89:121-128.

Hoelzel, A. R., A. Nataoli, M. E. Dahlheim, C. Olavarria, R. W. Baird, and N. A. Black. 2002. Low world-wide genetic diversity in the killer whale (Orcinus orca): Implications for demographic history. Proc. R. Soc. Lond. 269:1467-1473.

Hoyt, E. 1990. Orca, the whale called killer. 3rd ed. Camden House, Camden East, Ontario, Canada.

Jefferson, T. A., P. J. Stacey, and R. W. Baird. 1991. A review of killer whale interactions with other marine mammals: Predation to co-existence. Mammal Rev. 21:151-180.

Mobley, J. R. Jr., L. Mazzuca, A. S. Craig, M. W. Newcomer, and S. S. Spitz. 2001. Killer whales (Orcinus orca) sighted west of Ni'ihau, Hawai'i. Pac. Sci. 55:301-303.

Pitman, R. L., and P. H. Dutton. 2004. Killer whale predation on a leatherback turtle in the Northeast Pacific. Pac. Sci. 58:497498.

Pitman, R. L., and P. Ensor. 2003. Three forms of killer whales (Orcinus orca) in
Antarctic waters. J. Cetacean Res. Manage. 5:131-139.

Reid, S. B., J. Hirota, R. E. Young, and L. E. Hallacher. 1991. Mesopelagic-boundary community in Hawaii: Micronekton at the interface between neritic and oceanic ecosystems. Mar. Biol. (Berl.) 109:427-440.

Rizzuto, J. 2002. The Kona fishing chronicles 2002. Kona Fishing Chronicles, Kamuela, Hawai'i.

2004. The Kona fishing chronicles 2003/2004. Kona Fishing Chronicles, Kamuela, Hawai'i.

Roberts, A. C., and D. W. Meadows. 2004. Distribution and abundance of shortfinned pilot whales (Globicephala macrorbynchus) and other odontocetes in the four-island region of Hawaii. Unpubl. manuscript, available from D. W. Meadows, Hawai'i Division of Aquatic Resources, 2345 Ala Wai Boulevard, \#1107, Honolulu, Hawai'i 96815 (dwaynemeadows@msn.com).

Rosel, P. E., A. E. Dizon, and J. E. Heyning. 1994. Genetic analysis of sympatric morphotypes of common dolphins (genus Delphinus). Mar. Biol. (Berl.) 119:159-167.

Shimote, K. 2001. Whale foundation group spots orcas off Lanai. Honolulu StarBulletin, Honolulu, 4 September 2001.

Simila, T., J. C. Holst, and I. Christensen. 1996. Occurrence and diet of killer whales in northern Norway: Seasonal patterns relative to distribution and abundance of Norwegian spring-spawning herring. Can. J. Fish. Aquat. Sci. 53:769-779.

Stevens, T. A., D. A. Duffield, E. D. Asper, K. G. Hewlett, A. Bolz, L. J. Gage, and G. D. Bossart. 1989. Preliminary findings of restriction fragment differences in mitochondrial DNA among killer whales (Orcinus orca). Can. J. Zool. 67:2592-2595.

Wade, P. R., and T. Gerrodette. 1993. Estimates of cetacean abundance and distribution in the eastern tropical Pacific. Rep. Int. Whaling Comm. 43:477-493. 